\title{
Developing Knowledge and Leadership in Pre-Service Teacher Education Systems
}

\author{
Jo-Anne Ferreira, Lisa Ryan and Julie Davis
}

\begin{abstract}
Pre-service teacher education institutions are large and complex organizations, which are notoriously difficult to change. One factor is that many change efforts focus largely on individual pre-service teacher educators altering their practice. We report here on our experience using a model for effecting change, which views pre-service teacher education institutions and educators as a part of a much broader system. We identified numerous possibilities for, and constraints on, embedding change, but focus only on two in this paper: participants' knowledge of change strategies and their leadership capacities. As a result of our study findings and researcher reflections, we argue that being a leader in an academic area within pre-service teacher education does not equate to leadership knowledge or skills to initiate and enact systems-wide change. Furthermore, such leadership capacities must be explicitly developed if education for sustainability is to become embedded in pre-service teacher education.
\end{abstract}

\section{LEADERSHIP FOR CHANGE IN PRE-SERVICE TEACHER EDUCATION}

Pre-service teacher education institutions have achieved notoriety for their tendency to be large and complex organizations that are difficult to change (Fullan, 2013; McNamara, 2010; Tyack \& Cuban, 1995). For example, there have been over 30 years of efforts to ensure that first environmental education, and environmental education and education for sustainability ${ }^{1}$, becomes a constituent part of pre-service teacher education. However, we cannot yet say that this has occurred in Australia. In this paper, we briefly report on our experience trialing the Mainstreaming Change model we developed (Ferreira \& Ryan, 2012) as a guide for effecting change concurrently in many different parts of a broadly defined pre-service teacher education system. This broad definition includes key stakeholders in the teacher education system, that is, not only Schools of Education but also the universities in which they are located, teacher employing and registration authorities, professional associations and NGOs with an interest in teacher education. We identified a number of possibilities and constraints on change, such as leveraging on pre-existing change efforts, funding, and institutional support. One constraint of particular interest to us was participants' varying capacities for creating change and how these capacities influence or not the intended outcomes of change efforts. In this paper, we argue that being a leader in a field such as Education for Sustainability does not necessarily mean that one has leadership knowledge or skills to initiate and enact change. We discuss two dimensions of participants' 'change agent' capacity that emerged as problematic in our study - content knowledge and leadership skills - and argue that both these capacities must be explicitly developed if individuals are to lead change

\footnotetext{
${ }^{1}$ Since the emergence of 'education for sustainability' some 20 years ago, there has been much debate within the field of Environmental Education about the similarities and differences between the critical problem-solving and action oriented goals of environmental education (Stevenson, 2007; Fien 1993) and the more pragmatic, less political goals of education for sustainability (Tilbury 1995). We do not intend in this paper to conflate these two fields. While the focus in this project was on education for sustainability, we acknowledge the rich tradition of, and contribution that environmental education has made to the field of education for sustainability.
} 
that supports education for sustainability becoming a core component of pre-service teacher education.

\section{STUDY OVERVIEW}

Sustainability and Education for Sustainability are not new concerns; historically, there have been nearly three decades of efforts dedicated to 're-orienting' pre-service teacher education towards environmental education (and more recently including Education for Sustainability) (UNESCO, 1987, 2005). To date, these efforts have largely occurred through institutional professional development in Education for Sustainability for pre-service education academics - either individually, or in small groups (Ferreira, Ryan \& Tilbury, 2007), or, more commonly, as a result of the particular interest and/or dedication of individual academic staff members within preservice teacher education institutions (Fien, Kumar \& Ravindranath, 2001; Henderson \& Tilbury, 2004; Steele, 2010).

Despite such efforts, however, recent research indicates that pre-service teacher education institutions and programs in Australia are not adequately preparing teachers for teaching Education for Sustainability in schools (Miles, Harrison, \& CutterMackenzie, 2006; Ferreira, Ryan \& Tilbury, 2014; Boon, 2010). Indeed, recent research identifies that $80 \%$ of Australian teachers are either unaware of education for sustainability or do not understand what it is. Only $2 \%$ use education for sustainability teaching practices in their classroom (Australian Education for Sustainability Alliance (AESA), 2014). As we, and others, have noted (Fullan, 2013; Hargreaves \& Shirley, 2012; Frost, 2012; Ferreira \& Davis, 2015; Tom, 1997), sustaining curriculum change within education institutions is notoriously difficult. The loss or relocation of key champions for education for sustainability in teacher education, contextual constraints such as the increasing publication and teaching expectations placed upon staff (Wergin, 2007), and a constantly changing policy environment in pre-service teacher education have resulted in fragmented and poorly planned projects (Russell, McPherson \& Martin, 2001; Steele, 2010; AESA, 2014), which all impact on engagement with, and enthusiasm for, further change initiatives. As McNamara (2010, p. 49) argues, change is difficult because pre-service teacher education institutions are 'loosely coupled systems with a unique culture of collegial, bureaucratic, political, and anarchical systems and values'. For example, there are a number of contextual issues that impact on teacher education, such as a recognized conservatism now exacerbated by neoliberal imperatives in universities which focus on student outcomes in literacy and numeracy (Furlong, Barton, Miles, Whiting \& Witty, 2000; Mockler, 2013). We see this also in the recent review of the Australian curriculum (The Australian Government, 2014), where themes such as sustainability are no longer considered important.

In this paper we report on and discuss our efforts to overcome some of these shortcomings by adopting a systems-based approach to embedding Education for Sustainability into pre-service teacher education. Such an approach is argued to be consistent with the widespread and deep learning advocated by sustainability educators (Sterling, 2004). The research we report on here is drawn from our use of a theoretical model of change - 'Mainstreaming Change' (Ferreira \& Ryan, 2012) developed from an earlier analysis of change strategies used to embed Education for Sustainability in pre-service teacher education in Australia and internationally (Ferreira, Ryan and Tilbury, 2007). Little research has been undertaken on developing 
change agent capacity within the higher education context in general (Perry, 2010; Simoncini, Lasen \& Rocco, 2014), and we hope to contribute to the Australian and international literature on this issue. We investigate two types of capacity knowledge capacity and leadership capacity - and argue that, these should not be assumed as being already evident amongst either pre-service teacher educator change agents, or designated leaders within pre-service teacher education contexts (Kezar, 2012). It is our contention instead, that these capacities must be clearly and explicitly developed in education for sustainability projects that seek to achieve change in preservice teacher education. Leadership capacities are increasingly recognized as important in the transition to sustainability more generally (Fien, 2014).

As noted above, our aim in this paper is not to provide a detailed report on our use of the Mainstreaming Change model, but rather to focus on the issue of participants' (primarily pre-service teacher educators) knowledge and leadership capacities for change. Nevertheless, in order to provide some contextual background relevant to this particular study, we briefly describe the Mainstreaming Change model as well as providing an overview of the study aims, methods, outcomes and key findings. We conclude with a discussion of the need to develop leadership capacities.

\section{The Mainstreaming Change model}

The Mainstreaming Change model (Ferreira \& Ryan, 2012) is one of many proposed strategies aimed at overcoming the myriad of problems of initiating and sustaining changes in pre-service teacher education through using professional development activities. For example, projects such as the Australian Academy of Science's Primary Investigations (Aubusson \& Steele, 2002) and the Australian Government's Gifted Education Professional Learning Package (DEST/GERRIC, 2005) have utilized an innovation diffusion approach (train-the-trainer) (Rogers, 1995), while others have utilized participatory action research for more individualized approaches to change (Kennedy, 2013; Fien, Kumar \& Ravindranath, 2001). The Mainstreaming Change model seeks to utilize such approaches within an overarching framework for engaging with a whole system simultaneously (see, for example, Stevenson, Davis, Ferreira \& Evans, 2014), in line with calls within the field of education for sustainability to think systemically (Sterling, 2001; Wals \& Jickling, 2002; Henderson \& Tilbury, 2004; Lozano, Lukman, Lozano, Huisingh \& Lambrechts, 2013). In the project reflected on in this paper, the overarching goal was to facilitate change across a whole system, incorporating multiple people, parts and processes, which are involved in pre-service teacher education, including: schools; pre-service teacher education staff, administrators and students; unions; professional associations; registration authorities; and government agencies. The key goal of such an holistic approach is for change to occur concurrently across a number of policy-to-practice 'levels' within a pre-service teacher education system including governmental policy, accreditation and registration standards, course provisioning and teaching and learning processes.

The Mainstreaming Change model marries ideas from systems thinking (Meadows, 2009) with contemporary models of change (Fullan, 2013; Kotter, 2012) and of leadership (Fien, 2014; Tremblay, 2012; Kania \& Kramer, 2011; Spillane, Halverson $\&$ Diamond, 2001) to provide a process for achieving broad change across a whole pre-service teacher education system, while at the same time achieving 'deep' change 
through supporting participants to engage directly with processes of change. As we have argued elsewhere (Ferreira \& Ryan, 2012, p. 13):

The model is based on the assumption that long-term sustained change is most likely to occur when a common vision for change is widely shared throughout a system, and when all members of that system are collectively supported to operate in ways that are consistent with the common vision. It is our contention that such an approach could mainstream a change across multiple levels of a system and work to create commitment to and ownership of change across a whole system.

The model proposes a 3-part process for sustaining change, and provides markers about 'how to' achieve change, as shown in Table 1 below.

\begin{tabular}{|l|l|}
\hline Focus & Possible Strategies \\
\hline Working with Pre-Service & $\begin{array}{l}\text { Identify the system and its components (the individual organizations } \\
\text { that are involved in the system) }\end{array}$ \\
\cline { 2 - 3 } & $\begin{array}{l}\text { Delineate system boundaries in order to understand what can and } \\
\text { cannot be influenced and changed }\end{array}$ \\
\cline { 2 - 3 } & $\begin{array}{l}\text { Map and understand the nature of the relationships between system } \\
\text { components (for example, client, competitor, or resource provider) }\end{array}$ \\
\cline { 2 - 3 } Working with People & $\begin{array}{l}\text { Identify and involve hubs or change agents with disproportionate } \\
\text { influence within and across the system to provide points of leverage } \\
\text { for desired change }\end{array}$ \\
\hline Working for Change & $\begin{array}{l}\text { Build a common vision amongst all stakeholders for the change that } \\
\text { is to be achieved, in ways that develop ownership of that change }\end{array}$ \\
\cline { 2 - 3 } & $\begin{array}{l}\text { Use action research processes to build participants' capacities for } \\
\text { change and to continuously monitor and adapt change strategies }\end{array}$ \\
\hline $\begin{array}{l}\text { Develop effective communication strategies across the system to } \\
\text { support coordinated and strategic approaches aligned to the } \\
\text { collaborative vision for change, not only amongst active change } \\
\text { agents, but also more broadly amongst system members. }\end{array}$ \\
\cline { 2 - 2 } \begin{tabular}{l} 
Continuously evaluate and monitor the change processes at all \\
system levels and across all participants \\
\cline { 2 - 3 } Celebrate successful incremental changes
\end{tabular} \\
\hline
\end{tabular}

Table 1: Strategies For Achieving Systems Change (adapted from Ferreira \& Ryan, 2012)

While systems based approaches to change, such as The Mainstreaming Change model, are gaining support there have been critiques. For example, Caldwell (2012) argues that in such change models, the links between practice and learning, and agency and change are not well theorized. However, others argue that such approaches offer innovative ways to overcome the problems of sustaining long-term change initiatives (Fullan, 2013; Hargreaves \& Shirley, 2012) within complex organizations and systems. Through collaborative, multi-level and cross institutional visions and strategies for change that are cognizant of individual participant's roles and relationships within the pre-service teacher education system, the Mainstreaming Change model offers a unique approach to change management.

\section{Conduct of the Study}

The aim of our project was to trial the effectiveness or not of the Mainstreaming Change, model in achieving systems-based change in the pre-service teacher education systems of Queensland and the Northern Territory, each distinctly different from and independent of one another. Specifically, the project was targeted at 
increasing both the profile and provision of Education for Sustainability within preservice teacher education in these state/territory systems. Therefore, our project was simultaneously and synergistically an Education for Sustainability capacity-building project, a pre-service teacher education system change management project, and a research project aimed at evaluating the effectiveness of the Mainstreaming Change model for effecting change in pre-service teacher education.

The overall study drew upon a variety of theoretical frameworks and methods including organizational change, systems theory, and a participatory action research method (Mills, 2010; Tripp, 2005; Wadsworth, 1998). These choices were premised on the theoretical alignment between action research and the Education for Sustainability and systems thinking fields, and the need for alignment between the purposes and aims of education for sustainability and the research methods and processes used (Robottom \& Hart, 1993; Hart, 2013). For example, all three encourage: successive cycles of adaptive planning and critical reflection and learning; situated participatory learning and research processes that are contextually driven; and emergent and transformational outcomes that are focused on practical improvement (Wadsworth, 1998; Kemmis \& McTaggert, 2000; Barabasi, 2003; Tripp, 2005; Stone \& Barlow, 2005; Senge, 2006; Mills, 2010; Sterling, 2011; Tilbury, 2012).

The overall study was undertaken over a period of 16 months. Four months were spent in project planning and preparation, which included identifying, recruiting and training potential participants from pre-service teacher education institutions and related institutions and organizations. Participants were mainly identified through known networks in Education for Sustainability, and hence were already considered to be leaders in this field. This was followed by eight months using the model, gathering data from baseline context surveys, as well as built-in formative monitoring and evaluation procedures; and four months undertaking a reflective meta-analysis of the project results. Ethics approval was obtained from all participating universities ethics committees. Participants attended a series of group workshops, which included a mix of learning about action research and systems approaches to change, as well as opportunities to reflect upon and discuss their thoughts and experiences of managing systems change. Drawing distantly located participants together was difficult at times, so participants also kept learning journals for personal reflection and for sharing during a Community of Inquiry (Garrison, Anderson \& Archer, 1999). The Community of Inquiry used platforms such as email, teleconferences, Skype and Facebook. Facebook proved to be especially useful for connecting our pre-service teacher participants with each other and with the project. We also maintained a member-only-access website where project documents could be filed and shared confidentially. These also provided sources of data for the allied research, and ethical clearance was gained from participants at the commencement of the project to utilize records of meetings and shared journals as data sources.

Key outcomes of the overall study in pre-service teacher education faculties of the participating universities in Queensland and the Northern Territory include:

- Enhanced knowledge about and skills in Education for Sustainability, developed through workshops, conferences, staff seminars, and shared resources between academics from a range of disciplines, administrators, and pre-service teachers in participating teacher education institutions; 
- Changes in teaching and learning practices, including new courses and programs, new content, and the adoption of new teaching and learning pedagogies;

- A Community of Inquiry for project participants within and between institutions and States/Territories. This Community of Inquiry met both face-to-face and by phone and video chat to discuss experiences, issues and to share resources;

- New institutional positions and policies on sustainability and Education for Sustainability were developed; and

- New relationships between elements of the pre-service teacher education system were forged. For example, academics from pre-service teacher education institutions engaged with policy developers in government agencies and teacher registration authorities in developing briefing papers for relevant Ministers and departmental heads.

Hence, our study indicates that the change model for embedding sustainability into pre-service teacher education did have some usefulness in generating changes within these two teacher education systems. However, our research also highlighted constraints on the full achievement of systemic change. Of particular note were the knowledge and leadership dimensions that impacted on participants' capacities to initiate and lead systems change within their own contexts, that is, to be effective change agents within their own institutions/organizations. As we indicated in our introduction, the focus of the remainder of this paper is on elucidating these dimensions and discussing their importance within systems change.

\section{DEVELOPING LEADERSHIP CAPACITY FOR CHANGE}

In our study, and as we discuss further below, we found that systemic change requires project participants with particular knowledge and leadership capabilities. Issues arose relating to 1) the adequacy of participants' knowledge bases about action research and systems change, and 2) their personal leadership capacities. In essence, being an academic or professional leader in Education for Sustainability did not automatically ensure that one would be an effective leader of systems change for sustainability. We discuss these findings here and propose a number of issues for consideration for those also wishing to engage in systems change, whether they use the Mainstreaming Change model or other similar approaches or models. We argue that leading systems change initiatives requires developing both content knowledge and leadership skills. It is, therefore, of utmost importance that in systems-change projects, attention is paid to individual participants' knowledge and leadership capacities, and to enhancing these. Issues relating to each of these capacities are discussed below.

\section{Knowledge capacity for system-wide change in pre-service teacher education} Understanding systems-based organizational change emerged as a key issue in our study. To effect change across a complex system such as pre-service teacher education, change is required within and across a wide range of institutions such as universities, government agencies, statutory authorities and schools. Therefore, an indepth understanding of one's own organization and its relationships with other parts of the system is an essential starting point for systems change projects. Organizations are complex, and are shaped by a plethora of historical and environmental factors consisting of entrenched beliefs, values, and cultures often expressed as unquestioned, normalized daily practices (Frost, 2012). When complex organizational cultures are 
viewed through the framework of a system, the complexity and at times fragmented nature becomes even more evident. Our experiences indicate that it is vitally important to learn how systems work and how organizations - as elements of a system - can change. This is especially so when working within large systems such as preservice teacher education, which often seem to be resistant to broad-scale change. As others have found, this is because individuals either do not want to change; do not see the changes as relevant; do not feel they have a mandate to implement such a change; have conflicting incentives within the organization; and/or simply have a different worldview to that being promoted by the project (Fullan, 2013; Hargreaves \& Shirley, 2012; Kotter, 2012, 1995; Senge, Kleiner, Roberts, Ross, Roth, \& Smith, 1999; Drew, 2010; McNamara, 2010).

In seeking to address the issue of our study participants' inadequate knowledge bases and understandings about change, a range of strategies consistent with those advocated in the literature for managing organizational change (Kotter, 2012, 1995; Senge, et al., 1999; Higgs \& Rowland, 2000) were implemented by the project leaders. For example, project leaders in Queensland and the Northern Territory capitalized on their regular reporting schedules to the overall project funding bodies/managers and discussions with institutional participants as a way of identifying knowledge gaps, and then sought to address these either directly with participants (through phone and email advice, provision of appropriate articles to read, guest speakers/ 'experts' at workshops, and so on). Another effective strategy was the phone-based Community of Inquiry where group discussions deliberately focused on problematizing and clarifying a range of diverse conceptual understandings about key topics in order to build knowledge capacity for systems change. The range of challenges and the strategies we utilized to address these are briefly outlined in Table 2 below.

\begin{tabular}{|l|l|}
\hline Challenge & Strategy \\
\hline $\begin{array}{l}\text { Conflicting or discontinuous understandings of } \\
\text { Education for Sustainability amongst project } \\
\text { participants }\end{array}$ & $\begin{array}{l}\text { Collaboratively built a shared vision of Education } \\
\text { for Sustainability and shared understandings of } \\
\text { change. }\end{array}$ \\
\hline $\begin{array}{l}\text { Education for Sustainability systems change } \\
\text { initiative not seen as relevant to others in the } \\
\text { organization/institution }\end{array}$ & $\begin{array}{l}\text { Shared a range of strategies such as 'professional } \\
\text { conversations' (Haigh, 2005) for engaging others } \\
\text { and for building a shared vision for change. }\end{array}$ \\
\hline $\begin{array}{l}\text { Change agents lack authority or mandate to enact } \\
\text { change at levels beyond their own individual } \\
\text { practice }\end{array}$ & $\begin{array}{l}\text { Shared a range of strategies to enable participants } \\
\text { to become effective change leaders such as } \\
\text { showing how it is done, including skeptics and } \\
\text { resisters, and obtaining external validation. }\end{array}$ \\
\hline $\begin{array}{l}\text { Conflicting agendas/ other imperatives within the } \\
\text { institution }\end{array}$ & $\begin{array}{l}\text { Framing Education for Sustainability as good } \\
\text { quality pre-service teacher education because it } \\
\text { promotes effective pedagogies such as trans- } \\
\text { disciplinary inquiry learning, real world problem- } \\
\text { based learning, and active learning. }\end{array}$ \\
\hline $\begin{array}{l}\text { Institutional values and worldview conflict with } \\
\text { the proposed change agenda }\end{array}$ & $\begin{array}{l}\text { Sharing stories of successful change that began } \\
\text { with small-scale changes. }\end{array}$ \\
\hline
\end{tabular}

Table 2: Emerging Challenges and Change Strategies from Community of Inquiry

Both project participants and project leaders identified a lack of knowledge about systems change in complex and fragmented organizations. To remedy this, participants and leaders together identified and sought the assistance of an external consultant in change management who provided ongoing advice and support as well as professional development around change management for all participants. 
Consequently, these project leaders also circulated readings on systemic change to all participants within their project network, and made use of an on-line discussion forum to facilitate, for example, discussions around the differences between Environmental Education and Education for Sustainability, which then highlighted for the project leaders the range of different conceptual understandings held by institutional participants. The data gathered from project participant discussions and researcher reflections allowed project leaders to frame a more nuanced, flexible and responsive approach to change for participants that was specific and situated within their own context.

\section{Leadership capacity for system-wide change in pre-service teacher education} According to Fullan (2013) and Hargreaves \& Shirley (2012), pre-service teacher education systems, and the organizations within them, have historically been rooted within a hierarchical and authoritarian culture expressed through top-down decisionmaking and policy processes. While there has been significant change in recent times, the vestiges of this culture remain (Fullan, 2013; Hargreaves \& Shirley, 2012). Indeed, these cultural factors often lead to assumptions that change leadership is the sole responsibility of those in formal leadership positions such as Heads of Schools or chief policy officers, and that 'valid professional knowledge can only be created and disseminated by authorized agencies' (Frost, 2012, p. 223).

Numerous studies have identified the limitations of relying only on top-down leadership for creating and sustaining change (Fullan, 2011; Fullan \& Scott, 2009). Pearce \& Conger (2003), for example, argue that over-reliance on formal leaders can lead to lack of creative complexity in developing solutions, with poor participation and buy-in, and can also create a culture of leader dependence. There is a new body of research emerging that focuses on how grassroots or bottom-up leaders (individuals without positions of authority who act as agents of change without the benefits of formal power) are able to effect change (Kezar, 2012; Fullan \& Scott, 2009). In this project we explored a range of systems and leadership concepts such as 'transformational leadership' (Fien, 2014), 'networked leadership' (Davis \& Ferreira, 2009; Tremblay, 2012), 'collective impact' (Kania \& Kramer, 2011) and 'distributed leadership' (Spillane, et.al., 2001). The Mainstreaming Change model is based on a networked leadership approach, which is quite different from the traditional hierarchical leadership approach prevalent in many educational institutions and government departments. A networked leadership approach views leadership as distributed throughout an organization, not just at 'the top', and as involving a group of people in an organization, not just one (Kania \& Kramer, 2011).

Identifying leaders became a major issue in this project. State-based project participants in effect self-identified as leaders within their system, but the shortcoming of such a process, as we discovered through this project was that these individuals were leaders who had academic or professional credibility in Education for Sustainability, but not necessarily the skills for leading systems change. The outcome was that those who were appointed as project leaders had varying degrees of capacity to facilitate a change process, as was observed when these participants were asked to undertake leadership tasks in their individual institutions. Problematically, some did not see themselves, as noted in discussions and the Community of Inquiry, as being in a position to create change. Thus, there were impacts on the success of some projects as a result of these initial choices. 
The main issues in our project related to individuals' willingness to initiate project activities, their personal perceptions of their capacity to bring about change, and their abilities to inspire and lead others in a change process. This also impacted on the understanding and involvement of others within the system in the process of change. For these reasons, it became clear that we not only needed to develop participants' knowledge of change and change strategies, but also to develop their personal capacities for leadership. However, the tight project timeframe and limited resources required participants to be active in seeking to facilitate change in their systems from the start of the project. This left little scope for an initial induction into the project. To address this, we deployed a range of strategies including support and suggestions via email and phone; meetings organized within regions to encourage the local project leaders to engage more widely across their system; and appointing an organizational change consultant to assist project leaders. In addition, some of the participants, in recognizing their shortcomings in driving change processes, utilized the concept of 'convergence' (Kezar, 2012, p. 726) to try to increase their change influence. Here participants strategically joined their efforts, as 'grassroots leaders', with those in formal positions of authority (Pearce \& Conger, 2003). Several participants in our project strategically targeted formal leaders within relevant institutions to gain support for the project, which in turn led to more energy and enthusiasm for the change process and included more participants from across the system in the change process.

It became clear by the end of the project, however, that in order to be an effective leader, one must not only be in a position through which change can be effected within an organization, but must also believe one is able to initiate and drive change. Indeed, our findings gathered from participants throughout the project, and our own reflections as action researchers, indicate that a lack of belief in one's own capacity to bring about change has a greater negative effect on change than not being in a recognized position of power or authority within an organization. This was evidenced by project leaders who were not in formal positions of power but who, none-the-less, were able to effect change in curriculum, student engagement and the policies and processes of their organizations. In summary, it became clear through this project that in order for individuals to be effective leaders they need to:

- See themselves as leaders who are able to influence, effect and drive change within their organization;

- Be willing to act as advocates for the change the project is attempting to achieve;

- Have an interest in the key issue that they can clearly articulate;

- Show a commitment to the ideals of the project; and

- Have leadership skills to encourage and engage others in the change process.

\section{LEARNING TO BE LEADERS FOR CHANGE}

It has become clear through this project, similar to other research on leading systems change projects (Fullan, 2013; Fullan \& Scott, 2009), that if long-term, widespread change is to be achieved in pre-service teacher education, not only must one attend to the macro level of understanding and changing the whole system, including political factors and influences, but also to the micro level of the individuals who are seeking to enact change, and the interaction between these two. While change agents may have skills and knowledge that seem to align with the purposes of the project, our 
research has shown that possessing appropriate academic and professional knowledge associated with the 'target' change is not enough. Pre-service teacher educators also need to learn how to be leaders for change. This requires explicit learning processes that support project participants in identifying their current understandings of leadership and in gaining new understandings about, and strategies for, leading change. If not attended to, then change projects being implemented in pre-service teacher education and more broadly across universities and other large organizations, will continue to struggle to achieve their hoped-for goals and outcomes.

\section{AUTHOR BIOGRAPHIES}

Jo-Anne Ferreira convenes the Master of Environment (Education for Sustainability) program in the Griffith School of Environment, Brisbane, Australia. Jo-Anne's research field is sociology of education, with a special interest in post-structuralist theories of identity, embodiment and power, and environmental and sustainability education. Recent research focuses on systems-based change in teacher education and on strategies and techniques deployed by environmental and sustainability educators to empower learners to become environmental citizens.

Lisa Ryan is an Associate Lecturer in Sustainability Education at the University of the Sunshine Coast, Australia. Her research focuses on the professional development of sustainable schools teachers and systems approaches to change within teacher education. Her current $\mathrm{PhD}$ research draws on postcolonial theories to explore how Eco-Schools teachers are negotiating global eco-schooling discourses in their local contexts.

Julie Davis is Associate Professor of Early Childhood Education at Queensland University of Technology, Brisbane, Australia. Her research interests are two-fold: early childhood education for sustainability focused on nurturing young children's capacities as agents of change; and embedding education for sustainability in teacher education through systemic change approaches.

\section{REFERENCES}

Australian Education for Sustainability Alliance (AESA). (2014). Education for Sustainability and the Australian Curriculum Project: Final report for research phases 1 to 3. Melbourne: AESA.

Australian Government, The. (2014). Review of the Australian Curriculum: Final report. Canberra: The Australian Government Department of Education.

Aubusson, P. \& Steele, F. (2002). Evaluation of primary investigations. Canberra: Australian Academy of Science \& the Commonwealth Department of Education, Science and Training \& Sydney University of Technology.

Barabasi, A. (2003). Links: How everything is connected to everything else and what it means for business, science and everyday life. London: Penguin Books.

Boon, H. (2010). Climate change? Who knows? A comparison of secondary students and pre-service teachers. Australian Journal of Teacher Education. 35(1), 104120.

Caldwell, R. (2012). Systems thinking, organizational change and agency: A practice theory critique of Senge's learning organization. Journal of Change Management. 12(2), 145-164. 
Davis, J. and Ferreira, J. (2009). Creating cultural change in education: A proposal for a continuum for evaluating the effectiveness of sustainable schools implementation strategies. Australian Journal of Environmental Education. 25, 59-70.

DEST/GERRIC (Dept. of Education, Science and Training/ Gifted Education Research, Resource and Information Centre). (2005). Gifted and talented education: Professional development package for teachers. Sydney: DEST/GERRIC.

Drew, G. (2010). Issues and challenges in higher education leadership: Engaging for change. The Australian Educational Researcher. 37(3), 57-76.

Ferreira, J. and Davis, J. (2015). Using research and a systems approach to mainstream change in early childhood education for sustainability. In. J. Davis (Ed.) Young children and the environment: Early education for sustainability. (301-316) $2^{\text {nd }}$ Edition. Cambridge: Cambridge University Press.

Ferreira, J. \& Ryan, L. (2012). Working the system: A model for system-wide change in pre-service teacher education. Australian Journal of Teacher Education. $37(12), 29-45$.

Ferreira, J., Ryan, L. \& Tilbury, D. (2007). Mainstreaming Education for Sustainable Development in Initial Teacher Education in Australia: A review of existing professional development models. Journal of Education for Teaching. 33(2), 225-239.

Ferreira, J., Ryan, L. \& Tilbury, D. (2014). Planning for success: Factors influencing change in teacher education. Australian Journal of Environmental Education. 30(1), 136-146.

Fien, J. (1993). Education for the environment: Critical curriculum theorising and environmental education. Geelong: Deakin University.

Fien, J. (2014). Chasing the honey bee: Enhancing leadership for sustainability. Melbourne: Swinburne Leadership Institute Working Paper, No. 4, May 2014.

Fien, J., Kumar, P. \& Ravindranath, M.J. (2001). An action research network as a strategy for educational change: The learning for a sustainable environment project. Journal of Educational Change. 2(3), 207-221.

Frost, D. (2012). From professional development to system change: Teacher leadership and innovation. Professional Development in Education. 38(2), 205227.

Fullan, M. (2011). Change leader: Learning to do what matters most. San Francisco, CA.: Jossey-Bass.

Fullan, M. (2013). Motion leadership in action: More skinny on becoming change savvy. Thousand Oaks: Sage/Corwin Press.

Fullan, M. \& Scott, G. (2009). Turnaround leadership for higher education. San Francisco, CA.: Jossey-Bass.

Furlong, J., Barton, L., Miles, S., Whiting, C. \& Whitty, G. (2000). Teacher education in transition: Re-forming professionalism. Buckingham, UK: Open University Press.

Garrison, D.R., Anderson, T. \& Archer, W. (1999). Critical inquiry in a text-based environment: Computer conferencing in higher education. The Internet and Higher Education. 2(2-3), 87-105.

Henderson, K. \& Tilbury, D. (2004). Wholes-school approaches to sustainability: An international review of whole-school sustainability programs. Canberra: Report Prepared by the Australian Research Institute in Education for Sustainability 
(ARIES) for the Australian Government Department of the Environment, Water, Heritage and the Arts.

Haigh, N. (2005). Everyday conversation as a context for professional learning and development. International Journal for Academic Development 10(1): 3-16.

Hargreaves, A. \& Shirley, D. (2012). The global fourth way: The quest for educational excellence. Thousand Oaks: Sage/Corwin Press.

Hart, P. (2013). Methodology. In J. Dillon, M. Brody, R. Stevenson, \& A. Wals (Eds.) International handbook of research on environmental education. New York: Routledge.

Higgs M. \& Rowland, D. (2000). Building change leadership capability: 'The quest for change competence'. Journal of Change Management. 1(2), 116-130.

Kania, J. \& Kramer, M. (2011). Collective impact. Stanford Social Innovation Review. Winter, 36-41.

Kemmis, S., \& McTaggart, R. (2000). Participatory action research. In N. Denzin \& Y. Lincoln (Eds.), Handbook of qualitative research (pp. 567-605). Sage: Beverly Hills, CA.

Kennedy, C. (2013). Models of change and innovation. In K. Hyland \& L. Wong (Eds.), Innovation and change in English language education (pp. 13-27) Abingdon and New York: Routledge.

Kezar, A. (2012). Bottom-up/top-down leadership: Contradiction or hidden phenomenon. The Journal of Higher Education. 83(5), 725-760.

Kotter, J. P. (1995). Leading change: Why transformation efforts fail. Harvard Business Review. March-April, 11-16.

Kotter, J. P. (2012). The heart of change: Real-life stories of how people change their organizations. Cambridge, MA: Harvard Business Press Books.

Lozano, R., Lukman, R., Lozano, F., Huisingh, D. \& Lambrechts, W. (2013). Declarations for sustainability in higher education: Becoming better leaders, through addressing the university system. Journal of Cleaner Production. 48, $10-19$.

McNamara, K. H. (2010). Fostering sustainability in higher education: A mixedmethods study of transformative leadership and change strategies. Environmental Practice. 12(1), 48-58.

Meadows, D. (2009). Leverage points: Places to intervene in a system. Solutions. 1(1), 41-49

Miles, R., Harrison, L., \& Cutter-Mackenzie, A. (2006). Teacher education: A diluted environmental education experience. Australian Journal of Environmental Education, 22(1), 49.

Mills, G. (2010). Action research. New York: Pearson.

Mockler, N. (2013). Teacher professional learning in a neo-liberal age: Audit, professionalism and identity. Australian Journal of Teacher Education, 38(10), $35-47$.

Pearce, C. \& Conger, J. (2003). Shared leadership. Thousand Oaks, CA: Sage Publications.

Perry, J. A. (2010). Reclaiming the education doctorate: Three cases of processes and roles in institutional change. $\mathrm{PhD}$ thesis, College Park, MD, University of Maryland.

Robottom, I. \& Hart, P. (1993) Research in environmental education: Engaging the debate. Geelong: Deakin University.

Rogers, E. M. (1995). Diffusion of innovations (5th ed.). New York: The Free Press. 
Russell, T., McPherson, S. \& Martin, A. (2001). Coherence and collaboration in teacher education reform. Canadian Journal of Education, 26(1), 37-55

Senge, P., Kleiner, A., Roberts, C., Ross, R., Roth, G. \& Smith, B. (1999). The dance of change: The challenges to sustaining momentum in learning organizations. New York: Doubleday.

Senge, P. (2006). The fifth discipline: The art and practice of the learning organisation. New York: Random House.

Simoncini, K. M., Lasen, M., \& Rocco, S. (2014). Professional dialogue, reflective practice and teacher research: Engaging early childhood pre-service teachers in collegial dialogue about curriculum innovation. Australian Journal of Teacher Education, 39(1), 27-44.

Spillane, J., Halverson, R. \& Diamond, J. (2001). Investigating school leadership practice: A distributed perspective. Educational Researcher. 30(3), 23-28.

Steele, F. (2010). Mainstreaming education for sustainability in pre-service teacher education in Australia: Enablers and constraints. Canberra: Prepared by the Australian Research Institute in Education for Sustainability for the Australian Government Department of the Environment, Water, Heritage and the Arts.

Sterling, S. (2001). Sustainable education: Re-visioning learning and change, Dartington: Schumacher Society Briefing no. 6 \& Green Books.

Sterling, S. (2004). Higher education, sustainability, and the role of systemic learning. In P. Corcoran and A. Wals (Eds). (2004). Higher education and the challenge of sustainability: Problematics, promise, and practice (pp. 49-70). Dordrecht, The Netherlands: Kluwer Academic.

Sterling, S. (2011). Transformative learning and sustainability: Sketching the conceptual ground. Learning and Teaching in Higher Education. 5. 17-33.

Stevenson, R., Davis, J., Ferreira, J. \& Evans, N. (2014) A state systems approach to embedding the learning and teaching of sustainability in teacher education. Sydney: Office for Learning and Teaching.

Stevenson, R. (2007). Schooling and environmental education: Contradictions in purpose and practice. Environmental Education Research. 13(2): 139-153.

Stone, M.K. and Barlow, Z. (Eds) (2005). Ecological literacy: Educating our children for a sustainable world. San Francisco: Sierra Club Books.

Tilbury, D. (1995). Environmental education for sustainability: Defining the new focus of environmental education in the 1990s. Environmental Education Research. 1(2), 195-212.

Tilbury, D. (2012). Another world is desirable: Transforming higher education for sustainability. In S. Sterling, L. Maxey, and H. Luna (Eds.) The sustainable university: Process and prospects. (pp 71-85) London: Earthscan/Routledge.

Tom, A. R. (1997). Redesigning teacher education. Albany: State University of New York Press.

Tremblay, C. W. (2012). Network leadership: An emerging practice. College and University. 87 (4), 37-42.

Tripp, D. (2005). Action research: A methodological introduction, Educacao e Pesquisa (Education and Research), 31(3), 443 - 466.

Tyack, D., \& Cuban, L. (1995). Tinkering towards Utopia: A century of public school reform. Cambridge, MA: Harvard University Press.

UNESCO. (1987). Environmentally educated teachers - The priority of priorities. Connect. $X V(1), 1-3$. 
UNESCO. (2005). Guidelines and recommendations for reorienting teacher education to address sustainability. Education for Sustainable Development in Action, Technical Paper No. 2 - 2005. Paris: UNESCO.

Wadsworth, Y. (1998). What is participatory action research? Action Research International, Paper 2.

Wals, A. \& Jickling, B. (2002). 'Sustainability' in higher education: from doublethink and newspeak to critical thinking and meaningful learning. Higher Education Policy. 15, 121-131.

Wergin, J. F. (2007). Leadership in place: How academic professionals can find their leadership voice. Bolton, MA: Anker Publishing Co. 